\title{
A Field Survey on Indoor Air Pollution in School Classrooms with Different Ventilation Methods
}

\author{
Ko Murakami ${ }^{1 *}$, Kenta Sakai ${ }^{1}$, Daisuke Nakamura ${ }^{1}$, Haruno Ishikawa ${ }^{2}$, Sayana Tsushima ${ }^{1}$, and Shin-ichi Tanabe $^{1}$ \\ ${ }^{1}$ Waseda University, 169-8555, Tokyo, Japan \\ ${ }^{2}$ Shizuoka Institute of Science and Technology, 437-0032, Shizuoka, Japan
}

\begin{abstract}
The purpose of this study was to investigate the actual indoor air quality within two elementary schools with different types of ventilation methods, and to obtain data pertaining to the emission of bioeffluents within the schools. Field surveys on indoor air quality were conducted at two public elementary schools in Tokyo, both equipped with air-conditioning systems. School-A was also equipped with a heatexchange ventilation system, while School-B did not have a ventilation system. Results of the study revealed that the target ventilation volume for the heat-exchange ventilation system in School-A was not achieved, indoor air quality in School-B was better in relatively cool conditions than School-A because of the habit of opening windows attached, there was a positive correlation between nonanal and decanal and $\mathrm{CO}_{2}$ concentration in summer, and the concentration of bioeffluents nonanal and decanal may be higher at high temperatures even under the same level of ventilation.
\end{abstract}

\section{Introduction}

The purpose of this study is to investigate the actual indoor air quality within two elementary schools with different types of ventilation systems, and to obtain data about the emission of bioeffluents within the schools.

Currently, the rate of air conditioning system installation in public elementary schools in Japan is rising [1]. This is due to the summer season in Japan being very hot, which can have a detrimental effect on children's health and productivity. Along with the increase in the rate of air-conditioning installations, in a school that do not have mechanical ventilation, sufficient amount of ventilation is not secure because of a decreasing in window open/close. Meanwhile, there are few school classrooms that do have mechanical ventilation systems; thus, there are few cases available with which to examine differences in the air quality of the classroom due to mechanical ventilation systems.

School environmental hygiene standards in Japan [2] recommend that the $\mathrm{CO}_{2}$ concentration in the classroom be $1500 \mathrm{ppm}$ or less. Since $\mathrm{CO}_{2}$ itself is not a body odor component, it is insufficient as an index for uniformly controlling perceived air pollution due to body odor in a classroom where various uses exist. In most classrooms, children are densely populated, so the quantity of bioeffluents has a large influence on the perceived deterioration of air quality. In order to understand what creates a positive classroom air environment, it is necessary to obtain knowledge on the emission of bioeffluents in the classroom.

In this paper, we report on the results of a survey over a period of two years of the air quality at School-A, which is equipped with a total heat-exchange ventilation system, and at School-B, which does not have a ventilation system. $\mathrm{CO}_{2}$ concentration and VOC concentration, including bioeffluents, were used as indicators of air quality.

\section{Method}

\subsection{Background on Target Schools}

To gain an understanding of the indoor air quality in conjunction with the use of air-conditioning, a field survey was conducted on elementary schools located in Tokyo, where all elementary schools and junior high schools are equipped with air-conditioning systems. In the S-ward, the subject of this field survey, $25 \%$ of the elementary schools contain a heat-exchange ventilation system, while the remaining elementary schools do not have ventilation systems, and ventilation is achieved by opening windows. The basic information of both schools is given in Table 1.

Table 1. The basic information of both schools

\begin{tabular}{|c|c|c|c|c|}
\hline & \multicolumn{2}{|c|}{ School-A } & \multicolumn{2}{|c|}{ School-B } \\
\hline Location & \multicolumn{4}{|c|}{ S-ward, Tokyo } \\
\hline Completion, Structure & \multicolumn{2}{|l|}{ 2009, RC } & \multicolumn{2}{|l|}{ 1974, RC } \\
\hline Ventilation System & \multicolumn{2}{|c|}{ Heat-Exchange } & \multicolumn{2}{|l|}{ None } \\
\hline Classroom Volume & \multicolumn{2}{|c|}{$172.8 \mathrm{~m}^{3}$} & \multicolumn{2}{|c|}{$189.0 \mathrm{~m}^{3}$} \\
\hline Opening Area & \multicolumn{2}{|c|}{$\begin{array}{l}\text { Corridor side: } 3.61 \mathrm{~m}^{2} \\
\text { Outside: } 6.08 \mathrm{~m}^{2}\end{array}$} & \multicolumn{2}{|c|}{$\begin{array}{l}\text { Corridor side: } 5.06 \mathrm{~m}^{2} \\
\text { Outside: } 5.40 \mathrm{~m}^{2}\end{array}$} \\
\hline Air-conditioning & \multicolumn{4}{|c|}{\begin{tabular}{|c|} 
Multiple Packed Unit System \\
\end{tabular}} \\
\hline \multirow[b]{2}{*}{$\begin{array}{c}\text { Classroom } \\
: \text { Number of Children }\end{array}$} & FY 2016 & FY 2017 & FY 2016 & FY 2017 \\
\hline & $\begin{array}{l}3-2: 33 \\
3-3: 34 \\
5-2: 33 \\
5-3: 34\end{array}$ & $\begin{array}{l}2-4: 32 \\
2-5: 31 \\
4-3: 32 \\
4-4: 32\end{array}$ & $\begin{array}{l}2-1: 24 \\
2-2: 24 \\
5-1: 40 \\
6-1: 40\end{array}$ & $\begin{array}{l}2-1: 19 \\
2-2: 20 \\
5-1: 24 \\
5-2: 24 \\
6-1: 39 \\
\end{array}$ \\
\hline
\end{tabular}

\footnotetext{
*Corresponding author: murakami@tanebe.arch.waseda.ac.jp
} 
Air-conditioning systems are installed in all the classrooms in both schools. In addition, a remote-control panel is installed in each classroom, so the functions of start/stop, temperature control, and air volume settings are controlled according to each teacher's judgement.

In School-A, remote-control panels for the heatexchange ventilation system are installed in each classroom. However, the teachers were instructed to have the system remain on 24 hours a day.

In School-B, since a ventilation system is not installed, it was assumed that the methods of ventilation within the building include opening of the corridor-side door and opening the windows that have access to outside air.

\subsection{Measurement}

To gain an understanding of the actual conditions throughout the year, the field survey was conducted for approximately two weeks in summer, autumn and winter in FY 2016, and in summer and winter in FY 2017. A summary of the field survey is given in Table 2. In addition, to further investigate the actual ventilation conditions in each classroom, as well as the actual operating conditions of the ventilation and airconditioning systems, an intensive measurement day was included during each measurement period. During the intensive measurement day, the air-conditioning and ventilation settings in each classroom, the open/closed status of the windows, and the number of people were visually examined. Only during the measurements in FY 2017 , VOC concentration was also measured once during class and then after school.

GC/MS analysis conditions are given in Table 3. Classroom air sampling was conducted once during class and once after school. During class, all the children were in the classroom, and after school there were no children in the classroom. For measurements during the summer, 1 $\mathrm{L}$ of classroom air was trapped in the Tenax TA at a flow rate of $50 \mathrm{~mL} / \mathrm{min}$. During the winter measurement, $3 \mathrm{~L}$ of classroom air was trapped in the Tenax TA at a flow rate of $100 \mathrm{~mL} / \mathrm{min}$. Then, VOC was detected by GC/MS. The detection limit was $2.0 \mu \mathrm{g} / \mathrm{m}^{3}$ for the summer measurement, and $1.0 \mu \mathrm{g} / \mathrm{m}^{3}$ for the winter measurement.

In this study, the classroom air samples were analyzed to determine the concentrations of acetone [3], nonanal [4], decanal [4], and 2-ethyl-1-hexanol [4] which are known as bioeffluents, and the concentration of TVOC. It is, important to note that these substances are not only emitted by the human body but also household goods and building materials.
Table 3. GC/MS analysis conditions

\begin{tabular}{|c|c|c|c|}
\hline \multirow{8}{*}{ 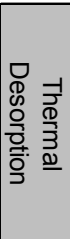 } & \multirow{4}{*}{ Sampling tube } & Desorption temperature & $260^{\circ} \mathrm{C}$ \\
\hline & & Desorption flow & $30 \mathrm{~mL} / \mathrm{min}$ \\
\hline & & Desorption time & $10 \mathrm{~min}$ \\
\hline & & Inlet split & $20 \mathrm{~mL} / \mathrm{min}$ \\
\hline & \multirow{4}{*}{ Trapping } & Trapping temperature & $5^{\circ} \mathrm{C}$ \\
\hline & & Desorption temperature & $280^{\circ} \mathrm{C}$ \\
\hline & & \begin{tabular}{|l|l|} 
Desorption time \\
\end{tabular} & $45 \mathrm{~min}$ \\
\hline & & Exit split & $10 \mathrm{~mL} / \mathrm{min}$ \\
\hline \multirow[b]{2}{*}{$\stackrel{\cap}{\Omega}$} & Column & \multicolumn{2}{|c|}{ HP-VOC $0.32 \varphi \times 60 m$ f.t. $1.8 \mu \mathrm{m}$} \\
\hline & Temperature & \multicolumn{2}{|c|}{$\begin{array}{c}35^{\circ} \mathrm{C}(2 \mathrm{~min})-\left(2.5^{\circ} \mathrm{C} / \mathrm{min}\right)-105^{\circ} \mathrm{C}- \\
\left(2.5^{\circ} \mathrm{C} / \mathrm{min}\right)-250^{\circ} \mathrm{C}(5 \mathrm{~min})\end{array}$} \\
\hline
\end{tabular}

\section{Results}

\subsection{Comparison between FY 2016 and FY 2017}

Weather conditions during survey period in summer are given in Fig. 1. In summer, the number of times the maximum temperature exceeded $30{ }^{\circ} \mathrm{C}$ during the measurement period was 5 in FY 2016 and 2 in FY 2017. In the summer of FY 2017 the weather was relatively cool.

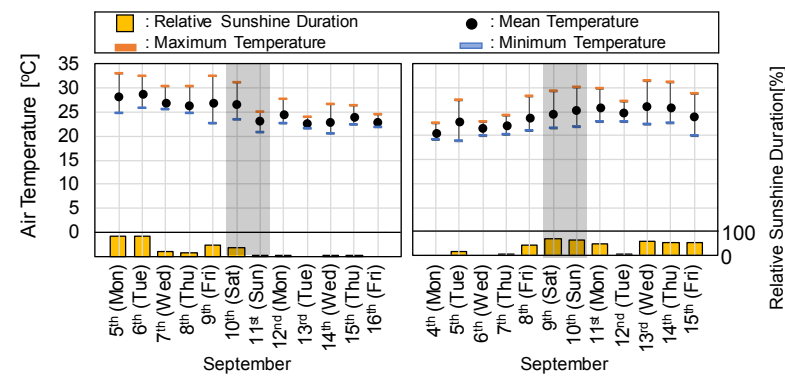

(a) Summer in FY 2016

(b) Summer in FY 2017

Fig. 1. Weather conditions during survey period in summer

The distribution of $\mathrm{CO}_{2}$ concentration in each classroom is given in Fig. 2. The numbers in the figure indicate the ratio of classroom air samples that exceeded $1500 \mathrm{ppm}$ of $\mathrm{CO}_{2}$. There are a certain number of time periods where the $\mathrm{CO}_{2}$ concentration exceeded the 1500 ppm level in both schools. In School-A, $46 \%$ of the classrooms exceeded the $1500 \mathrm{ppm}$ level in the winter of FY 2017, and only 5\% classrooms exceeded that level in the winter of FY 2016. Over the winter, number of classrooms measuring concentrations of $1500 \mathrm{ppm} \mathrm{CO}_{2}$ or more increased significantly from FY 2016 to FY 2017. In School-A, since the operation of total heat exchange ventilation is running in all classrooms, the possibility that the ventilation air volume of total heat exchange ventilation is decreasing was shown. In School-B, $2 \%$ of the classrooms exceeded $1500 \mathrm{ppm} \mathrm{CO}_{2}$ in the summer of FY 2017, and 23\% classrooms exceeded $1500 \mathrm{ppm}$ the summer of FY 2016. Over the summer, the number of

Table 2. A summary of the field survey

\begin{tabular}{|c|l|l|l|l|}
\hline & \multicolumn{2}{|c|}{ Measurement Period } & \multicolumn{1}{c|}{ Measurement Item } \\
\hline Measurement Year & \multicolumn{1}{|c|}{ FY 2016 } & \multicolumn{1}{c|}{ FY 2017 } & \multicolumn{1}{c|}{ Measurement Method } \\
\hline $\begin{array}{c}\text { Long Term } \\
\text { Measurement }\end{array}$ & $\begin{array}{l}\text { Summer : September 5-16 } \\
\text { Autumn : October 17-21 } \\
\text { Winter : December 5-16 }\end{array}$ & $\begin{array}{l}\text { Summer : September 4-15 } \\
\text { Autumn : None } \\
\text { Winter : February 2- March 9 }\end{array}$ & $\begin{array}{l}\text { Indoor air temperature } \\
\text { Outside air temperature } \\
\text { Relative humidity } \\
\text { CO }_{2} \text { concentration }\end{array}$ \\
\hline $\begin{array}{c}\text { Intensive } \\
\text { Measurement }\end{array}$ & $\begin{array}{l}\text { Summer : September 6/9 } \\
\text { Autumn : October 17/18 } \\
\text { Winter : December 12/13 }\end{array}$ & $\begin{array}{l}\text { Summer : September 5/11 } \\
\text { Autumn : None } \\
\text { Winter : March 5/8 }\end{array}$ & $\begin{array}{l}\text { Window opening/closing } \\
\text { Number of children in class } \\
\text { Use of air conditioning / ventilation facility } \\
\text { VOC concentration (only in FY 2017) }\end{array}$ \\
\hline
\end{tabular}


classrooms measuring $1500 \mathrm{ppm} \mathrm{CO}_{2}$ or more decreased significantly from FY 2016 to FY 2017. Since the measurement period in FY 2017 summer was relatively cool, it was suggested that windows were frequently opened in School-B.

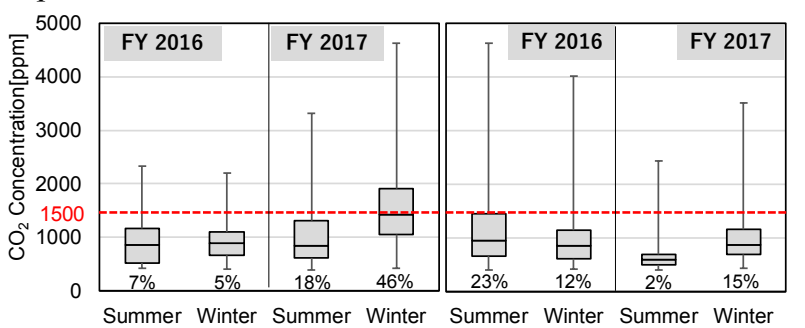

(a) School-A

(b) School-B

Fig. 2. The distribution of $\mathrm{CO}_{2}$ concentration in each classroom

\subsection{Comparison between both schools in FY 2017}

During the summer intensive measurement days in FY 2017, we measured the area of windows and doors opened during air-conditioning use for 24 classrooms at SchoolA and 10 classrooms at School-B. Relationship between windows and doors opening ratio and relative frequency during air-conditioning use is shown in Fig. 3. The horizontal axis shows the opened ratio to total opening area of windows and doors, and the vertical axis shows the relative frequency. In School-A, there were many time periods when the windows and doors were not opened, $59 \%$ when the opened ratio was 0 to $20 \%$, and $28 \%$ when the opened ratio was 20 to $40 \%$. For most, the opened window or door was the corridor side. On the other hand, in School-B, it was showed that $40 \%$ when the opened ratio was 40 to $60 \%$ and $20 \%$ when the opened ratio was 60 to $80 \%$. In the case of a relatively cool climate in summer, schools without ventilation systems tended to ventilate classrooms by opening windows and doors more often, compared to schools with ventilation facilities.

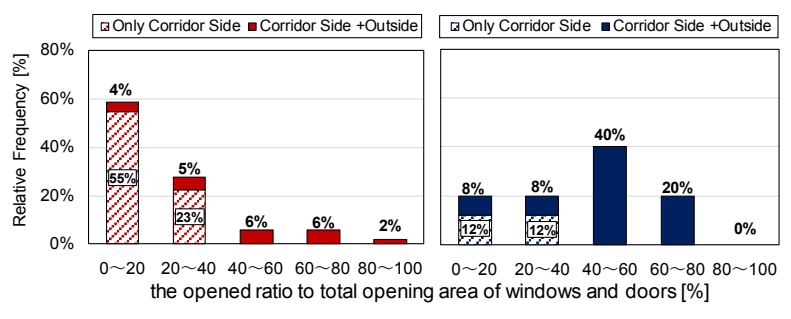

(a) School-A

(b) School-B

Fig. 3. Relationship between windows and doors opening ratio and relative frequency during air-conditioning use

\subsection{VOC concentration of both school}

Table 4 lists the classroom conditions when air samples were collected, including number of students present, sampling time, and $\mathrm{CO}_{2}$ concentration. VOC concentration of the samples collected during the summer is shown in Table 5. VOC concentration of the samples collected during the winter is listed in Table 6 . In winter, concentration of acetone was remarkably high, as much as $1420 \mu \mathrm{g} / \mathrm{m}^{3}$ in classrooms $2-5$ in School-A. In classrooms 2-5, a drawing and manual arts class was held on the measurement day, and it is assumed that the contribution of plastic adhesives and other to the high concentration of acetone in that room is considerable.

Table 4. The classroom conditions when air samples were collected

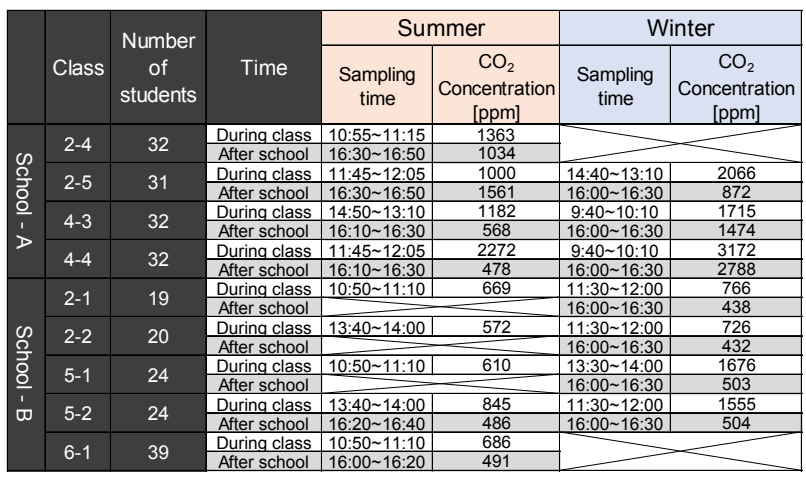

Table 5. VOC concentration of the samples collected during the summer

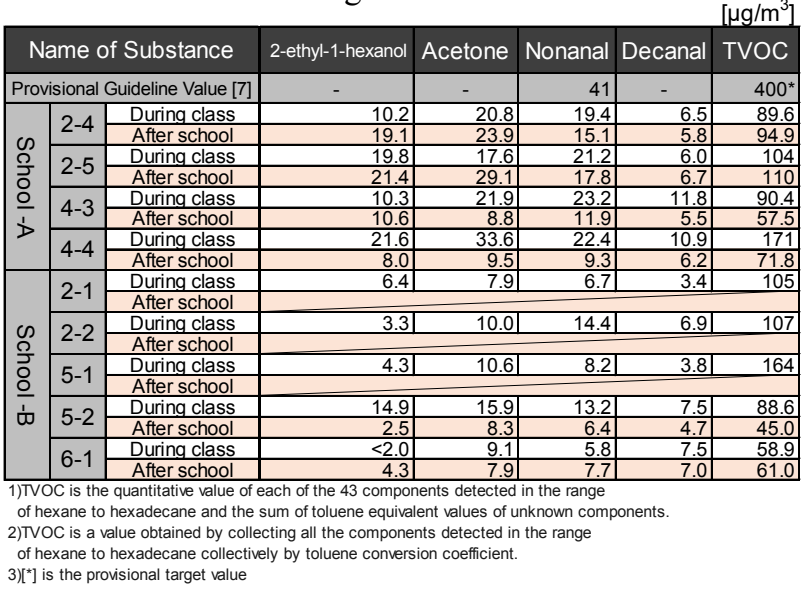

Table 6. VOC concentration of the samples collected during the winter

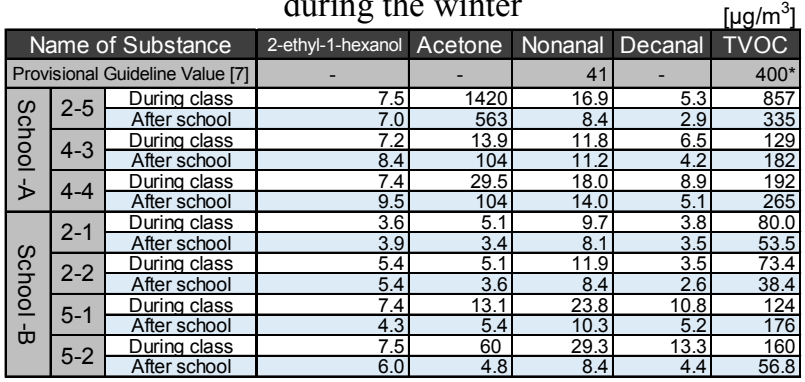

With respect to nonanal and decanal, in almost all classrooms, higher concentrations occurred during class than after school. On the other hand, the concentrations of 2-ethyl-1-hexanol and acetone did not exhibit much change between samples collected during class compared to after school. 2-ethyl-1-hexanol is emitted from building materials [5], acetone is emitted in large quantities from adhesives [6] and so it was assumed that most of the emissions originated somewhere other than the human body. In classrooms $2-5$ of School-A in winter, TVOC concentration was $857 \mu \mathrm{g} / \mathrm{m}^{3}$ and exceeded the provisional target value [7] of $400 \mu \mathrm{g} / \mathrm{m}^{3}$. On the other hand, in other classrooms it was below the provisional target value. It is possible that contaminants were generated in classrooms 2-5. 


\section{Discussion}

\subsection{Actual state of ventilation air volume of total heat exchange ventilation in School-A}

The relationship of the opened area ratio with $\mathrm{CO}_{2}$ concentration is given in Fig. 4. Regardless of whether the rate of opening area of window and door is high or low, $\mathrm{CO}_{2}$ concentration was kept below $1500 \mathrm{ppm}$ during most classroom hours in FY 2016. On the other hand, in FY 2017, when the rate was low, the tendency of $\mathrm{CO}_{2}$ concentration exceeding $1500 \mathrm{ppm}$ was remarkable. Considering the performance of the total heat-exchange ventilation in School-A, it is suggested that the total heatexchange ventilation may not have been operated according to the design volume in FY 2017 due to stain of the air filter, etc.

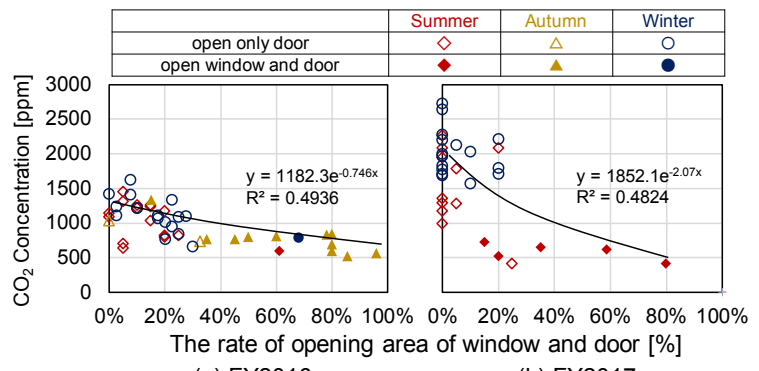
(a) FY2016
(b) FY2017

Fig. 4. The relationship of the opened area ratio with $\mathrm{CO}_{2}$ concentration

\subsection{Relationship between $\mathrm{CO}_{2}$ concentration and VOC concentration}

Relationship between $\mathrm{CO}_{2}$ concentration and VOC concentration is given in Fig. 5. The horizontal axis shows the average $\mathrm{CO}_{2}$ concentration during classroom air sampling and the vertical axis shows the concentration of each VOC in air. The air temperature in each classroom at the time of sampling was within the range of 24 to $29^{\circ} \mathrm{C}$ in summer and 20 to $24{ }^{\circ} \mathrm{C}$ in winter.

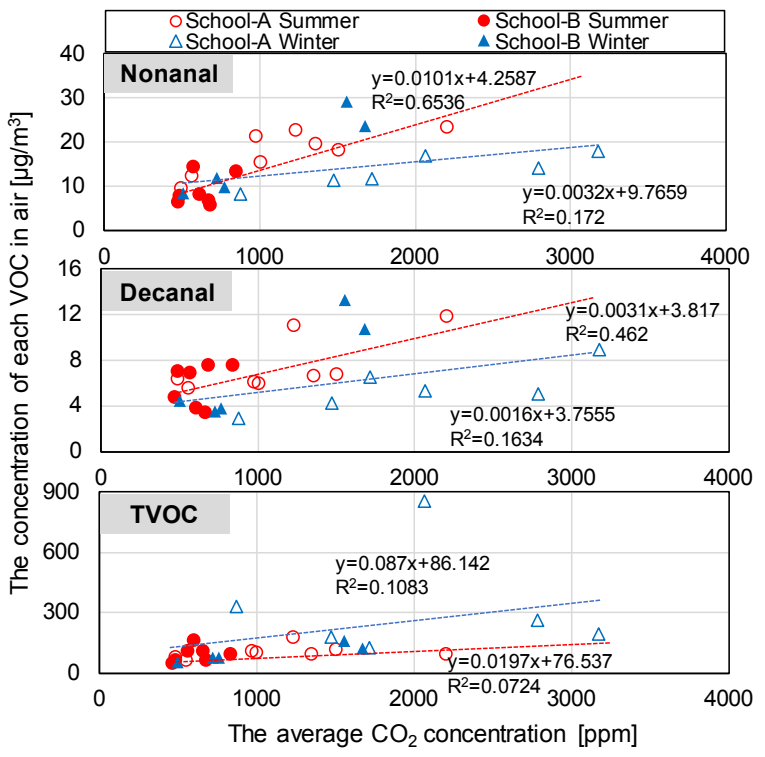

Fig. 5. Relationship between $\mathrm{CO}_{2}$ and VOC concentration
There was a positive correlation between nonanal and decanal and $\mathrm{CO}_{2}$ concentration in summer, and there was little correlation in winter. Since the sampling times during the summer and winter were not the same, they cannot be unconditionally compared. However, in summer, the skin exposed surface of the persons in the room is large, and it is conceivable that the influence of bioeffluents on the indoor air is greater due to this. Also, because the slope of the approximate line is larger in the summer than in the winter, distribution trends of $\mathrm{CO}_{2}$ concentration and VOC concentration may be different depending on the season. It is suggested that even under the same level of ventilation, the concentration of bioeffluents may be higher at high temperatures.

\section{Conclusion}

In this study, we conducted field surveys on the actual indoor air quality at two schools: School-A, where a heatexchange ventilation system was installed, and School-B, which did not have a ventilation system.

In School-A, over the winter, the $\mathrm{CO}_{2}$ concentration increased significantly from FY 2016 to FY 2017. It is suggested that the total heat exchanger may not have been operated according to the design volume in FY 2017. In School-B, over the summer, the $\mathrm{CO}_{2}$ concentration decreased significantly from FY 2016 to FY 2017. Since the measurement period in FY 2017 was relatively cool, it was suggested that windows were frequently opened in School-B.

There was a positive correlation between nonanal and decanal and $\mathrm{CO}_{2}$ concentration in summer. It is suggested that even under the same level of ventilation, the concentration of bioeffluents may be higher at high temperatures.

This research was subsidized by The Taisei Foundation, and supported by the Board of Education and the elementary schools of S-ward, Tokyo. The authors appreciate the contributions from all participants of this study.

\section{References}

1. Ministry of Education, 2017, On the result of the installation condition of the air conditioning equipment of public school facilities.

2. Ministry of Education, 2014, School environmental hygiene standards.

3. Y. Sekine, S. Toyooka, S. F. Watts, J. Chromatogr. B, 859, 201-207 (2007).

4. S. Haze, Y. Gozu, S. Nakamura, Y. Kohno, K. Sawano, H. Ohta, K. Yamazaki, J. Invest. Dermatol., 116 (4), 520-524 (2001).

5. M. Kamijima, E. Shibata, K. Sakai, H. Ohno, S. Ishihara, T. Yamada, Y. Takeuchi, T. Nakajima, Jpn. J. Public Health, 52 (12), 1021-1031 (2005).

6. A. Onuki, I. Saito, H. Seto, S. Uehara, H.Kamimura Ann. Rep. Tokyo Metr. Inst. P.H., 55 (2004).

7. Ministry of Health, Labor and Welfare, 2002, On the concept of TVOC formulation of air quality guidelines 